\title{
KREATIVITAS ENTREPRENEURIAL LEADERSHIP DALAM PEMBELAJARAN KEWIRAUSAHAAN PADA ANAK USIA DINI
}

\author{
Siti Fadjryana Fitroh, Dewi Mayangsari \\ Program Studi PG PAUD Fakultas Ilmu Pendidikan Universitas Trunojoyo Madura \\ e-mail: stfadjryana@yahoo.com, mayangsarie@gmail.com
}

\begin{abstract}
Abstrak
Karakteristik yang dimiliki anak usia dini adalah rasa ingin tahunya yang besar, hal ini membuat dirinya selalu memiliki keinginan untuk mengembangkan potensi yang dimilikinya untuk belajar. Anak memiliki kreativitas yang harus dikembangkan, sehingga membutuhka stimulus yang tepat untuk mengembangkan dapat melalui pembelajaran, yakni pembelajaran kewirausahaan. Pembelajaran kewirausahaan menjadi pilihan karena, perkembangan zaman menuntut seseorang untuk memiliki kreativitas dalam memimpin usahanya sendiri, maka dari itu sejak dini sudah diajarkan tentang kewirausahaan. Hal ini membuat penting untuk mengembangkan kreativitas entrepreneurial leadership pada anak sejak usia dini. Penelitian ini memiliki tujuan: 1) Bagaimana kreativitas entrepreneurial leadership AUD dalam pembelajaran; 2) Faktor yang muncul dalam peroses pengembangan kreativitas entrepreneurial leadership AUD. Subyek penelitian 6 anak, usia 5-6 tahun. Jenis penelitian adalah penelitian kualitatif deskriptif. Teknik pengumpulan datanya observasi, wawancara dan dokumentasi. Hasil penelitian menyatakan bahwa 1) anak dikatakan kreativitas entrepreneurial leadership saat pembelajaran kewirausahaan saat nilai aspek motivasi dan kreatifnya tinggi 2) Faktor pendukung dalam pengembangan kreativitas entrepreneurial leadership anak usia dini adalah sarana belajar, kemenarikan guru dan peran orang tua.
\end{abstract}

Kata kunci: kreativitas, entrepreneurial leadership, pembelajaran, anak usia dini

\section{CREATIVITY OF ENTREPRENEURIAL LEADERSHIP IN ENTREPRENEURSHIP LEARNING IN EARLY CHILDHOOD}

\begin{abstract}
The characteristics of the early childhood is his great curiosity, this makes him always have a desire to develop the potential he has to learn. Children to have creativity that must be developed. One of the right stimulus to develop children creativity can be through learning, namely entrepreneurial learning. Entrepreneurship learning becomes an option because, the development of the era demands a person to have creativity in leading his own business, therefore from an early age has been taught about entrepreneurship. This makes it important to develop the creativity of entrepreneurial leadership in children from an early age. This study has objectives: 1) how the creativity of entrepreneurial leadership of AUD in learning; 2) Factors that arise in peroses development of entrepreneurial leadership of AUD creativity. Research subjects 6 children, aged 5-6 years. The type of research is descriptive qualitative research. Data collection techniques of observation, interview and documentation. The result of the research stated that 1) the child is said to be creativity of entrepreneurial leadership during entrepreneurship learning when the aspect of motivation and creativity is high 2) Supporting factors in the development of creativity of early childhood entrepreneurial leadership are learning facilities, teacher attractiveness and parent role.
\end{abstract}

Keywords: creativity, entrepreneurial leadership, learning, early childhood

\section{PENDAHULUAN}

Tujuan pendidikan untuk anak usia dini adalah membentuk anak diusia 0-6 tahun, dapat tumbuh dan berkembang menjadi usia yang sangat produktif dalam mengembangkan segala macam potensi 
berdasarkan karakteristik yang dimiliki. Menurut Hartati (2005) menjelaskan bahwa karakteristik anak usia dini adalah 1) memiliki rasa ingin tahu yang besar; 2) memiliki pribadi yang unik; 3) suka berfantasi dan berimajinasi; 4) masa potensial untuk belajar; 5) memiliki sikap egosentris; 6) memiliki rentan daya konsentrasi yang pendek; dan 7) merupakan bagian dari mahluk sosial. Karakteristik di atas menggambarkan bahwa potensi harus dapat berkembang maksimal.

Dalam mengembangkan semua potensi di atas dibutuhkan kreativitas. Pada dasarnya semua anak sudah kreatif. Menurut Sujiono 2005 (dalam Nurhayati, 2011) menyatakan bahwa kreativitas yang ditunjukkan anak merupakan bentuk kreativitas yang original dengan frekuensi kemunculannya seolah tanpa terkendali. Selain itu, Munandar (2009) juga mengemukakan pentingnya pengembangan kreativitas pada anak antara lain: (1) kreativitas dapat mewujudkan aktualisasi diri; (2) kreativitas merupakan cerminan berpikir kreatif anak; (3) kreativitas bermanfaat bagi lingkungan sosial; dan (4) kreativitas memungkinkan manusia meningkatkan kualitas hidup.

Menurut Hurlock (2007) ada beberapa faktor yang dapat meningkatkan kreativitas antara lain a) Waktu untuk menuangkan ide/gagasan atau konsepkonsep original-nya; b) Kesempatan menyendiri untuk mengembangkan imajinasinya; c) Dorongan atau motivasi untuk kreatif, bebas dari ejekan; d) Sarana bermain untuk merangsang dorongan eksperimen dan eksplorasi. Selain itu ada hal lain yang juga perlu diperhatikan selain faktor, yakni beberapa kondisi yang dapat meningkatkan kreativitas, yaitu: 1) sarana belajar dan bermain disediakan untuk merangsang dorongan eksperimen dan eksplorasi; 2) lingkungan sekolah yang teratur, bersih, dan indah secara lansung akan mendorong kreativitas; 3) Kemenarikan guru dalam mendidik dan memberikan motivasi; 4) peran masyarakat dan orangtua mendukung kegiatan TK yaitu menyediakan media/bahan praktek senirupa (Depdikbud, 2005: 42).

Akhir-akhir ini banyak orang bersaing untuk menunjukkan hasil karya dari kreativitas yang dimiliki. Hal ini membuat banyak pameran produk-produk hasil kreativitas menjamur, dimana produk tersebut akan dijual belikan. Ternyata pameran tersebut juga membawa nama untuk Indonesia, karena produk-produk kreativitas tidak hanya dijual ekspor tetapi juga impor. Fenomena di atas menjadikan motivasi besar dalam dunia pendidikan, untuk meningkatkan kreativitas pada peserta didik khususnya anak usia dini. Dunia pendidikan melakukan upaya-upaya pengambil kebijakan dengan cara memasukkan peningkatan kreativitas dalam berbagai kegiatan pendidikan, baik dimuat dalam kurikulum, strategi pembelajaran maupun perangkat pembelajaran lainnya.

Penjelasan di atas merupakan bagian dari upaya agar setiap kegiatan pendidikan atau pembelajaran, dapat memfasilitasi peserta didik dalam mendapatkan keterampilan mengembangkan kreativitas terutama dalam memecahkan masalah. Mengembangkan kreativitas pada anak usia dini dalam proses pembelajaran sangatlah mudah, jika stimulus yang diberikan tepat. Dalam hal ini pemberian stimulasi dalam pembelajaran anak usia dini tidak jauh-jauh dengan konsep bermain, namun disaat bermain perlu penekanan tentang hikmah atau maksud dari permainan yang dilakukan, sehingga tidak terlihat hanya bermain saja, namun anak bisa belajar banyak hal. Dalam hal ini, pembelajaran yang tepat untuk mengembangkan kreativitas adalah pembelajaran kewirausahaan.

Kewirausahaan menurut Drucker adalah suatu kemampuan untuk menciptakan sesuatu yang baru dan berbeda. Hal ini dipertegas oleh Zimmerer (1996) bahwa kewirausahaan merupakan 
suatu proses penerapan kreativitas dan keinovasian dalam memecahkan persoalan dan menemukan peluang untuk memperbaiki kehidupan usaha. Selain itu kewirausahaan berperan sebagai tempat kegiatan pelatihan dan pendidikan dalam mengembangkan daya kreativitas dan inovasi bagi peserta didik dalam memahami suatu peluang, mengorganisasi, dan mengelola sumber daya- sumber daya yang sudah ada menjadi barang yang bernilai. Sedangkan pembelajaran kewirausahaan itu sendiri menurut Ruspiasih (2015) merupakan upaya yang sengaja dilakukan oleh pendidik atau guru untuk membelajarkan peserta didik tentang kewirausahaan agar mereka mengetahui kiat-kiat kewirausahaan dengan baik, sehingga dapat meningkatkan kompetensi pengetahuan, keterampilan, dan sikap yang diperlukan untuk menciptakan suatu peluang usaha. Dengan demikian dunia pendidikan akan memberikan kontribusi yang besar terhadap pengembangan SDM yang kreatif dan memiliki kemampuan pemecahan masalah yang handal untuk menjalani masa depan yang penuh tantangan.

Dalam mengembangkan kreativitas dibidang kewirausahaan harus memiliki jiwa kepemimpinan yang bagus dalam berwirausaha. Menurut Pattikumay, 2008 (dalam Sugianto \& Sutanto, 2013), menyatakan bahwa untuk membangun jiwa entrepreneurial leadership merupakan suatu tindakan perubahan yang mengarah kepada peningkatan kreativitas, inovasi, intuisi, dan kemampuan memimpin, motivasi, serta keberanian mengambil risiko. Adapun tujuannya saat anak sudah memiliki bekal jiwa entrepreneurial leadership maka anak akan memiliki keberanian, kemandirian serta ketrampilan, sehingga mampu meminimalisir kegagalan dalam dirinya sehingga tidak mudah putus asa dan terus berjuang serta optimis. Sedangkan kreativitas entrepreneurial leadership sendiri adalah anak dapat berpikir luwes dalam memimpin usahanya dengan bentuk peningkatan kreativitas, inovasi, intuisi, dan motivasi, serta keberanian mengambil risiko. Dalam penelitian ini difokuskan pada pembelajaran kewirausahaan sebagai stimulus melihat kreativitas entrepreneurial leadership. Untuk lebih jelasnya peneliti mengambil rumusan masalah sebagai berikut: 1) Bagaimana kreativitas entrepreneurial leadership AUD dalam pembelajaran kewirausahaan?; dan 2) Faktor-faktor apa saja yang muncul dalam peroses pengembangan kreativitas entrepreneurial leadership AUD?

\section{METODE}

Penelitian ini dilakukan di TK Tarbiyatus Sibyan Kamal dengan subjek anak Kelompok B usia 5-6 tahun sejumlah 6 orang. Metode penelitian yang digunakan adalah kualitatif pendekatan deskriptif naratif, Sumber data, yakni observasi, wawancara, dan dokumentasi. Menurut Moleong (2012) alur proses analisis, yakni: 1) Reduksi data yakni proses pemilihan, penyederhanaan, pengabstrakan dan transformasi data "kasar" yang muncul dari catatan yang tertulis di lapangan. 2) Penyajian Data yakni sekumpulan informasi yang tersusun memberi kemungkinan adanya penarikan kesimpulan bisa dengan bentuk grafik, maupun bagan. 3) Penarikan kesimpulan yakni proses mencari arti, mencatat keteraturan, pola-pola, penjelasan, konfigurasi yang mungkin, alur sebab akibat dan proposisi dari gambarangambaran secara keseluruhan baik catatan deskriptif maupun reflektif yang telah dibuat sebelumnya pada bagan.

\section{HASIL DAN PEMBAHASAN}

Kegiatan sebagai permulaan, anak diperkenalkan tentang apa itu berwirausaha terlebih dahulu lalu diperkenalkan tentang karakter seorang pengusaha. Berdasarkan hasil observasi, wawancara dan dokumentasi yang dilakukan peneliti selama pelaksanaan. Dalam melihat kreativitas entrepreneurial 
leadership disaat pembelajaran kewirausahaan melalui lima aspek yakni kreatif, inovasi, intuisi, motivasi, dan berani mengambil risiko.

Jika dilihat pada tabel 1 dapat dinyatakan bahwa hasil observasi menunjukkan aspek kreatif nilai tertinggi pada item berpikir luwes dan berpikir orisinil. Terbukti bahwa dari keenam subjek mencapai penilaian rata-rata $\mathrm{BSH}$ (berkembang sesuai harapan) dan BSB (berkembang sangat bagus). Jadi, anak dikatakan kreatif saat dia mampu berpikir luwes yang dimaksud adalah kemampuan anak dalam menghasilkan sebuah gagasan yang bervariasi, dan juga mampu berpikir orisinil maksudnya mampu menghasilkan karya yang berbeda. Hal ini nampak saat anak menyampaikan ide dalam sebuah gambar, anak mampu menghasilkan rancangan usaha yang akan dijalankan berbeda-beda. Dapat ditunjukkan dalam tabel 1.
Tabel 1. Hasil Observasi Aspek Kreatif Subjek

\begin{tabular}{|c|c|c|c|c|c|c|c|c|}
\hline \multirow{3}{*}{ I } & \multirow[t]{3}{*}{ Item } & \multirow[t]{3}{*}{ Pernyataan } & \multicolumn{6}{|c|}{ Subjek } \\
\hline & & & $\mathbf{D}$ & $\mathbf{D}$ & $\mathbf{I}$ & $\mathbf{A}$ & $\mathbf{F}$ & $\mathbf{L}$ \\
\hline & & & a & i & $\mathbf{n}$ & $\mathbf{r}$ & $\mathbf{i}$ & $\mathbf{S}$ \\
\hline \multirow[t]{11}{*}{1} & \multirow{11}{*}{$\begin{array}{c}\text { Berpikir } \\
\text { lan } \\
\text { car }\end{array}$} & Menghasilkan & $\mathrm{B}$ & $\mathrm{B}$ & $\mathrm{M}$ & $\mathrm{B}$ & $\mathrm{M}$ & $\mathrm{B}$ \\
\hline & & gagasan & $\mathrm{S}$ & $\mathrm{S}$ & $\mathrm{B}$ & $\mathrm{S}$ & B & $\mathrm{S}$ \\
\hline & & dengan cepat & $\mathrm{H}$ & $\mathrm{B}$ & & $\mathrm{H}$ & & $\mathrm{H}$ \\
\hline & & Mengembang & $\mathrm{B}$ & $\mathrm{B}$ & B & $\mathrm{B}$ & $\mathrm{M}$ & B \\
\hline & & kan gagaan & $\mathrm{S}$ & $\mathrm{S}$ & $\mathrm{S}$ & $\mathrm{S}$ & $\mathrm{B}$ & $\mathrm{S}$ \\
\hline & & & $\mathrm{B}$ & $\mathrm{H}$ & $\mathrm{B}$ & $\mathrm{H}$ & & B \\
\hline & & Menjawab & $\mathrm{B}$ & $\mathrm{M}$ & $\mathrm{B}$ & $\mathrm{B}$ & $\mathrm{M}$ & $\mathrm{B}$ \\
\hline & & pertayaan & $\mathrm{S}$ & $\mathrm{B}$ & $\mathrm{S}$ & $\mathrm{S}$ & $\mathrm{B}$ & $\mathrm{S}$ \\
\hline & & & $\mathrm{B}$ & & $\mathrm{B}$ & $\mathrm{B}$ & & B \\
\hline & & Tanggap & $\mathrm{M}$ & $\mathrm{B}$ & $\mathrm{M}$ & $\mathrm{B}$ & $\mathrm{M}$ & $\mathrm{M}$ \\
\hline & & memperbaiki & $\mathrm{B}$ & $\begin{array}{l}\mathrm{S} \\
\mathrm{B}\end{array}$ & $\mathrm{B}$ & $\begin{array}{l}\mathrm{S} \\
\mathrm{B}\end{array}$ & $\mathrm{B}$ & B \\
\hline & \multirow{6}{*}{$\begin{array}{c}\text { Berpikir } \\
\text { lu } \\
\text { wes }\end{array}$} & Menghasilkan & $\mathrm{B}$ & $\mathrm{B}$ & $\mathrm{B}$ & $\mathrm{B}$ & B & B \\
\hline & & gagasan & $\mathrm{S}$ & $\mathrm{S}$ & $\mathrm{S}$ & $\mathrm{S}$ & $\mathrm{S}$ & $\mathrm{S}$ \\
\hline & & bervariasi & $\mathrm{H}$ & $\mathrm{B}$ & B & B & B & B \\
\hline & & Memecahkan & $\mathrm{B}$ & $\mathrm{M}$ & $\mathrm{M}$ & $\mathrm{B}$ & $\mathrm{M}$ & $\mathrm{M}$ \\
\hline & & masalah & $\mathrm{S}$ & $\mathrm{B}$ & B & $\mathrm{S}$ & $\mathrm{B}$ & B \\
\hline & & & $\mathrm{B}$ & & & $\mathrm{B}$ & & \\
\hline \multirow[t]{9}{*}{3} & \multirow{9}{*}{$\begin{array}{c}\text { Berpikir } \\
\text { orisinil }\end{array}$} & Mengajukan & $\mathrm{B}$ & $\mathrm{B}$ & $\mathrm{B}$ & $\mathrm{B}$ & $\mathrm{M}$ & $\mathrm{B}$ \\
\hline & & gagasan baru & $\mathrm{S}$ & $\mathrm{S}$ & $\mathrm{S}$ & $\mathrm{S}$ & $\mathrm{B}$ & $\mathrm{S}$ \\
\hline & & & $\mathrm{B}$ & $\mathrm{B}$ & $\mathrm{B}$ & $\mathrm{B}$ & & B \\
\hline & & Membuat & $\mathrm{B}$ & $\mathrm{B}$ & $\mathrm{B}$ & $\mathrm{B}$ & M & $\mathrm{B}$ \\
\hline & & kombinasi & $\mathrm{S}$ & $\mathrm{S}$ & $\mathrm{S}$ & $\mathrm{S}$ & $\mathrm{B}$ & $\mathrm{S}$ \\
\hline & & kegiatan & $\mathrm{B}$ & $\mathrm{B}$ & $\mathrm{B}$ & $\mathrm{B}$ & & B \\
\hline & & Menghasilkan & $\mathrm{B}$ & $\mathrm{B}$ & $\mathrm{B}$ & $\mathrm{B}$ & B & B \\
\hline & & karyaberbeda & $\mathrm{S}$ & $\mathrm{S}$ & $\mathrm{S}$ & $\mathrm{S}$ & $\mathrm{S}$ & S \\
\hline & & & $\mathrm{B}$ & $\mathrm{B}$ & $\mathrm{B}$ & $\mathrm{B}$ & $\mathrm{B}$ & $\mathrm{B}$ \\
\hline \multirow[t]{5}{*}{4} & \multirow[t]{5}{*}{ Merinci } & Menjelaskan & $\mathrm{B}$ & $\mathrm{B}$ & $\mathrm{M}$ & $\mathrm{B}$ & $\mathrm{M}$ & $\mathrm{B}$ \\
\hline & & gagasan & $\mathrm{S}$ & $\mathrm{S}$ & $\mathrm{B}$ & $\mathrm{S}$ & $\mathrm{B}$ & $\mathrm{S}$ \\
\hline & & dengan rinci & $\mathrm{B}$ & B & & B & & B \\
\hline & & menghasilkan & $\mathrm{M}$ & $\mathrm{M}$ & $\mathrm{M}$ & B & $\mathrm{M}$ & $\mathrm{M}$ \\
\hline & & $\begin{array}{c}\text { karya dengan } \\
\text { teliti }\end{array}$ & $\mathrm{B}$ & $\mathrm{B}$ & $\mathrm{B}$ & $\begin{array}{l}\mathrm{S} \\
\mathrm{B}\end{array}$ & $\mathrm{B}$ & B \\
\hline \multirow[t]{6}{*}{5} & \multirow[t]{6}{*}{ Menilai } & Mengutarakan & $\mathrm{B}$ & $\mathrm{M}$ & $\mathrm{B}$ & $\mathrm{B}$ & $\mathrm{M}$ & $\mathrm{B}$ \\
\hline & & pendapat & $\mathrm{S}$ & $\mathrm{B}$ & $\mathrm{S}$ & $\mathrm{S}$ & $\mathrm{B}$ & $\mathrm{S}$ \\
\hline & & & $\mathrm{B}$ & & $\mathrm{B}$ & $\mathrm{B}$ & & B \\
\hline & & Menentukan & $\mathrm{B}$ & $\mathrm{B}$ & $\mathrm{M}$ & $\mathrm{B}$ & $\mathrm{B}$ & B \\
\hline & & pilihan secara & $\mathrm{S}$ & $\mathrm{S}$ & $\mathrm{B}$ & $\mathrm{S}$ & $\mathrm{S}$ & $\mathrm{S}$ \\
\hline & & mandiri & $\mathrm{B}$ & $\mathrm{B}$ & & $\mathrm{B}$ & $\mathrm{B}$ & B \\
\hline
\end{tabular}

Keterangan:

BB : Belum Berkembang

MB : Masih Berkembang

BSB : Berkembang Sangat Bagus

BSH : Berkembang Sesuai Harapan 
Tabel 2. Hasil Observasi Aspek Inovasi Subjek

\begin{tabular}{|c|c|c|c|c|c|c|c|c|}
\hline \multirow{2}{*}{$\begin{array}{l}\mathbf{N} \\
\mathbf{0}\end{array}$} & \multirow[t]{2}{*}{ Item } & \multirow{2}{*}{$\begin{array}{c}\text { Pernyataa } \\
\text { n }\end{array}$} & \multicolumn{6}{|c|}{ Subjek } \\
\hline & & & $\begin{array}{l}\text { D } \\
\text { a }\end{array}$ & $\begin{array}{l}\text { D } \\
\text { i }\end{array}$ & $\begin{array}{l}\text { I } \\
\mathbf{n}\end{array}$ & $\begin{array}{l}\mathbf{A} \\
\mathbf{r}\end{array}$ & $\begin{array}{l}\mathbf{F} \\
\mathbf{i}\end{array}$ & $\begin{array}{l}\mathbf{L} \\
\mathbf{S}\end{array}$ \\
\hline \multirow[t]{5}{*}{1} & \multirow{5}{*}{$\begin{array}{c}\text { Terbu } \\
\text { ka } \\
\text { pada } \\
\text { perub } \\
\text { ahan }\end{array}$} & Menghasil & $\mathrm{M}$ & $\mathrm{M}$ & B & $\mathrm{M}$ & $\mathrm{M}$ & $\mathrm{M}$ \\
\hline & & $\begin{array}{l}\text { kan karya } \\
\text { baru dari } \\
\text { pendapat } \\
\text { orlan }\end{array}$ & B & $\mathrm{B}$ & $\begin{array}{l}\text { S } \\
\text { B }\end{array}$ & B & B & B \\
\hline & & Menciptak & B & B & M & B & M & M \\
\hline & & an hal baru & $\mathrm{S}$ & $\mathrm{S}$ & B & $\mathrm{S}$ & B & B \\
\hline & & $\begin{array}{c}\text { sesuai } \\
\text { keinginan }\end{array}$ & B & B & & $\mathrm{H}$ & & \\
\hline \multirow[t]{6}{*}{2} & \multirow{6}{*}{$\begin{array}{l}\text { Panda } \\
\text { ngan } \\
\text { peluan } \\
\text { g }\end{array}$} & Mengkreas & $\mathrm{M}$ & B & B & B & B & $\mathrm{M}$ \\
\hline & & ikan bahan & B & $\mathrm{S}$ & $\mathrm{S}$ & $\mathrm{S}$ & $\mathrm{S}$ & B \\
\hline & & baru sesuai & & B & B & B & B & \\
\hline & & ide & & & & & & \\
\hline & & $\begin{array}{l}\text { Melinat } \\
\text { situasi }\end{array}$ & $\begin{array}{l}B \\
S\end{array}$ & $\begin{array}{l}B \\
S\end{array}$ & $\begin{array}{l}\mathrm{M} \\
\mathrm{B}\end{array}$ & $\begin{array}{l}B \\
S\end{array}$ & $\begin{array}{l}\mathrm{M} \\
\mathrm{B}\end{array}$ & $\begin{array}{l}B \\
S\end{array}$ \\
\hline & & $\begin{array}{c}\text { untuk } \\
\text { berkompeti } \\
\text { si }\end{array}$ & B & B & & B & & B \\
\hline \multirow[t]{7}{*}{3} & \multirow{7}{*}{$\begin{array}{c}\text { Peren } \\
\text { canaa } \\
\mathrm{n}\end{array}$} & Mengamba & B & B & $\mathrm{M}$ & B & $\mathrm{M}$ & B \\
\hline & & rkan awal & $\mathrm{S}$ & $\mathrm{S}$ & B & $\mathrm{S}$ & B & $\mathrm{S}$ \\
\hline & & $\begin{array}{c}\text { rencana } \\
\text { impian }\end{array}$ & B & B & & $\mathrm{H}$ & & B \\
\hline & & Menceritak & B & B & $\mathrm{M}$ & B & $\mathrm{M}$ & B \\
\hline & & an & $\mathrm{S}$ & $\mathrm{S}$ & B & $\mathrm{S}$ & B & $\mathrm{S}$ \\
\hline & & sederhana & B & B & & $\mathrm{H}$ & & B \\
\hline & & $\begin{array}{c}\text { tentang } \\
\text { rencana } \\
\text { usaha }\end{array}$ & & & & & & \\
\hline
\end{tabular}

Jika dilihat pada tabel 2 dapat dinyatakan bahwa hasil observasi menunjukkan aspek Inovasi hampir seimbang belum bisa dikatakan ada item yang dominan dari keenam subjek. Namun nampak dalam penilaian ada aspek yang mencapai nilai BSH (berkembang sesuai harapan), yakni terbuka pada perubahan, yakni pada hal menciptakan sesuatu yang baru sesuai keinginan dan pada perencanaan, yakni mampu menggambarkan awal rencana impian serta mampu bercerita sederhana tentang rencana usaha yang akan dijalankan.

Tabel 3. Hasil Observasi Aspek Intuisi Subjek

\begin{tabular}{|c|c|c|c|c|c|c|c|}
\hline \multirow{2}{*}{$\begin{array}{l}\text { N } \\
\text { o }\end{array}$} & Pernyataan & \multicolumn{5}{|c|}{ Subjek } \\
\cline { 3 - 7 } & & D & D & I & A & F & L \\
\hline 1 & & a & i & n & r & i & s \\
\hline & Merasakan & B & B & B & B & B & B \\
& menjadi pengusaha & S & S & S & S & B & S \\
& & B & B & B & B & & B \\
\hline 2 & Menjelaskan & B & M & M & B & M & B \\
& spontan gambar & S & B & B & S & B & S \\
& usahanya & H & & & B & & B \\
\hline
\end{tabular}

\begin{tabular}{|c|c|c|c|c|c|c|c|}
\hline 3 & Menghasilkan hasil & M & B & M & B & B & B \\
& karya sesuai & B & S & B & S & S & S \\
& hatinya & & B & & B & B & B \\
\hline 4 & Menggambil & M & M & M & B & M & M \\
& hikmah akan yang & B & B & B & S & B & B \\
& sudah dilakukan & & & & B & & \\
\hline 5 & Memberi kesan & B & M & B & B & M & B \\
& tentang yang sudah & S & B & S & S & B & S \\
& dipelajari & B & & B & B & & B \\
\hline
\end{tabular}

Jika dilihat pada tabel 3 dapat dinyatakan bahwa hasil observasi menunjukkan aspek Intuisi hampir seimbang, belum bisa dikatakan ada item yang dominan dari ke enam subjek.

Tabel 4. Hasil Observasi aspek Motivasi Subjek

\begin{tabular}{|c|c|c|c|c|c|c|c|c|}
\hline \multirow{3}{*}{$\begin{array}{l}\mathbf{N} \\
\mathbf{0}\end{array}$} & \multirow[t]{3}{*}{ Item } & \multirow[t]{3}{*}{ Pernyataan } & \multicolumn{6}{|c|}{ Subjek } \\
\hline & & & D & D & & & & $\mathbf{L}$ \\
\hline & & & $\mathbf{a}$ & i & n & $\mathbf{r}$ & i & $\mathbf{s}$ \\
\hline \multirow[t]{9}{*}{1} & \multirow{9}{*}{$\begin{array}{l}\text { Kesena } \\
\text { ngan, } \\
\text { kenika } \\
\text { matan } \\
\text { belajar }\end{array}$} & kemauan & B & $\mathrm{B}$ & $\mathrm{B}$ & $\mathrm{B}$ & $\mathrm{B}$ & $\mathrm{B}$ \\
\hline & & mengikuti & $\mathrm{S}$ & $\mathrm{S}$ & $\mathrm{S}$ & $\mathrm{S}$ & $\mathrm{S}$ & $\mathrm{S}$ \\
\hline & & kegiatan & $\mathrm{H}$ & $\mathrm{B}$ & $\mathrm{B}$ & $\mathrm{H}$ & $\mathrm{B}$ & $\mathrm{B}$ \\
\hline & & senang & B & B & $\mathrm{B}$ & $\mathrm{B}$ & B & B \\
\hline & & mengikuti & S & $\mathrm{S}$ & $\mathrm{S}$ & $\mathrm{S}$ & $\mathrm{S}$ & $\mathrm{S}$ \\
\hline & & kegiatan & $\mathrm{H}$ & $\mathrm{H}$ & $\mathrm{H}$ & $\mathrm{H}$ & B & $\mathrm{H}$ \\
\hline & & fokus & $\mathrm{B}$ & $\mathrm{B}$ & $\mathrm{B}$ & $\mathrm{B}$ & $\mathrm{M}$ & $\mathrm{B}$ \\
\hline & & mengikuti & S & $\mathrm{S}$ & $\mathrm{S}$ & $\mathrm{S}$ & B & $\mathrm{S}$ \\
\hline & & kegiatan & B & B & B & $\mathrm{H}$ & & B \\
\hline \multirow[t]{6}{*}{2} & \multirow{6}{*}{$\begin{array}{l}\text { Pengua } \\
\text { saan } \\
\text { materi }\end{array}$} & melakukan & $\mathrm{B}$ & $\mathrm{B}$ & $\mathrm{B}$ & $\mathrm{B}$ & $\mathrm{M}$ & $\mathrm{B}$ \\
\hline & & kegiatan & S & $\mathrm{S}$ & $\mathrm{S}$ & $\mathrm{S}$ & B & $\mathrm{S}$ \\
\hline & & $\begin{array}{c}\text { yang sudah } \\
\text { dipelajari }\end{array}$ & B & B & B & B & & B \\
\hline & & mengungkap & M & B & $M$ & B & M & $\mathrm{B}$ \\
\hline & & kan kegiatan & B & $\mathrm{S}$ & B & $\mathrm{S}$ & B & $\mathrm{S}$ \\
\hline & & $\begin{array}{c}\text { yang } \\
\text { dipelajari }\end{array}$ & & B & & B & & $\mathrm{B}$ \\
\hline \multirow[t]{6}{*}{3} & \multirow{6}{*}{$\begin{array}{c}\text { Dorong } \\
\text { an ingin } \\
\text { tahu } \\
\text { kuat }\end{array}$} & aktif & $\mathrm{M}$ & $\mathrm{M}$ & $\mathrm{M}$ & $\mathrm{M}$ & $\mathrm{B}$ & $\mathrm{B}$ \\
\hline & & bertanya, & B & B & $\mathrm{B}$ & B & B & $\mathrm{S}$ \\
\hline & & $\begin{array}{l}\text { berpartisipasi } \\
\text { dalam } \\
\text { pembelajaran }\end{array}$ & & & & & & B \\
\hline & & rasa ingin & $\mathrm{B}$ & $\mathrm{B}$ & $\mathrm{M}$ & $\mathrm{B}$ & $\mathrm{M}$ & $\mathrm{B}$ \\
\hline & & tahu tinggi & S & $\mathrm{S}$ & B & $\mathrm{S}$ & B & $\mathrm{S}$ \\
\hline & & & B & B & & B & & B \\
\hline \multirow[t]{6}{*}{4} & \multirow{6}{*}{$\begin{array}{l}\text { Keuleta } \\
\text { n } \\
\text { mengerj } \\
\text { akan } \\
\text { tugas }\end{array}$} & menyelesaik & B & $\mathrm{B}$ & $\mathrm{B}$ & $\mathrm{B}$ & $\mathrm{B}$ & $\mathrm{B}$ \\
\hline & & an kegiatan & $\mathrm{S}$ & $\mathrm{S}$ & $\mathrm{S}$ & $\mathrm{S}$ & $\mathrm{S}$ & $\mathrm{S}$ \\
\hline & & hingga akhir & $\mathrm{H}$ & $\mathrm{B}$ & $\mathrm{H}$ & B & B & $\mathrm{B}$ \\
\hline & & menerima & B & B & B & B & $\mathrm{B}$ & $\mathrm{B}$ \\
\hline & & tugas yang & S & $\mathrm{S}$ & $\mathrm{S}$ & $\mathrm{S}$ & $\mathrm{S}$ & $\mathrm{S}$ \\
\hline & & $\begin{array}{l}\text { diberikan } \\
\text { guru }\end{array}$ & $\mathrm{H}$ & $\mathrm{H}$ & B & $\mathrm{H}$ & B & B \\
\hline \multirow[t]{6}{*}{5} & \multirow{6}{*}{$\begin{array}{c}\text { Keterlib } \\
\text { atan }\end{array}$} & mengikuti & B & B & $\mathrm{B}$ & $\mathrm{B}$ & $\mathrm{B}$ & $\mathrm{B}$ \\
\hline & & proses cara & S & $\mathrm{S}$ & S & $\mathrm{S}$ & $\mathrm{S}$ & $\mathrm{S}$ \\
\hline & & $\begin{array}{l}\text { pembuatan } \\
\text { karya }\end{array}$ & $\mathrm{H}$ & $\mathrm{H}$ & $\mathrm{H}$ & B & B & B \\
\hline & & terlibat & $\mathrm{B}$ & B & B & $\mathrm{B}$ & $\mathrm{B}$ & B \\
\hline & & membuat & S & $\mathrm{S}$ & $\mathrm{S}$ & $\mathrm{S}$ & S & $\mathrm{S}$ \\
\hline & & karya & $\mathrm{H}$ & $\mathrm{H}$ & $\mathrm{H}$ & B & B & B \\
\hline
\end{tabular}


Jika dilihat pada tabel 4 dapat dinyatakan bahwa hasil observasi menunjukkan aspek Motivasi nilai tertinggi pada item kesenangan belajar, keuletan mengerjakan tugas, dan keterlibatan. Terbukti bahwa dari keenam subjek mencapai penilaian rata-rata $\mathrm{BSH}$ (berkembang sesuai harapan) dan BSB (berkembang sangat bagus). Jadi anak memiliki motivasi tinggi saat memiliki kesenangan dalam belajar yang dimaksud adalah anak senang mengikuti kegiatan dalam hal ini kegiatan berwirausaha, ulet dalam mengerjakan tugas, yakni mampu menerima tugas yang diberikan guru dan mampu terlibat maksudnya terlibat dalam pembuatankarya dan mengikuti tiap proses pembuatan karya. Saat pembelajaran kewirausahaan anak tampak antusias mulai dari pembuatan produk, pengemasan hingga penjualan, anak mampu menjalankan tugas yang diberikan oleh guru.

Tabel 5. Hasil Observasi Aspek Berani Ambil Risiko Subjek

\begin{tabular}{|c|c|c|c|c|c|c|c|c|}
\hline \multirow{2}{*}{$\begin{array}{l}\mathbf{N} \\
\mathbf{0}\end{array}$} & \multirow[t]{2}{*}{ Item } & \multirow{2}{*}{$\begin{array}{c}\text { Pernyataa } \\
\text { n }\end{array}$} & \multicolumn{6}{|c|}{ Subjek } \\
\hline & & & $\begin{array}{l}\text { D } \\
\text { a }\end{array}$ & $\begin{array}{l}\mathbf{D} \\
\mathbf{i}\end{array}$ & \begin{tabular}{l|} 
I \\
n
\end{tabular} & $\begin{array}{l}\mathbf{A} \\
\mathbf{r}\end{array}$ & $\begin{array}{l}\mathbf{F} \\
\mathbf{i}\end{array}$ & $\begin{array}{l}\mathbf{L} \\
\mathbf{S}\end{array}$ \\
\hline \multirow[t]{5}{*}{1} & \multirow{5}{*}{$\begin{array}{c}\text { Beran } \\
\text { i } \\
\text { tanya } \\
\text { dan } \\
\text { ditan } \\
\text { ya }\end{array}$} & & B & $\mathrm{M}$ & $\mathrm{M}$ & B & $\mathrm{M}$ & B \\
\hline & & & $\begin{array}{l}\text { S } \\
\text { B }\end{array}$ & B & B & $\begin{array}{l}\mathrm{S} \\
\mathrm{B}\end{array}$ & B & $\begin{array}{l}\mathrm{S} \\
\mathrm{B}\end{array}$ \\
\hline & & berani & B & B & $\mathrm{M}$ & B & $\mathrm{M}$ & B \\
\hline & & menja & $\mathrm{S}$ & $\mathrm{S}$ & B & $\mathrm{S}$ & B & S \\
\hline & & & B & B & & $\mathrm{B}$ & & B \\
\hline \multirow[t]{6}{*}{2} & \multirow{6}{*}{$\begin{array}{c}\text { Rasa } \\
\text { perca } \\
\text { ya } \\
\text { diri }\end{array}$} & & B & $\mathrm{M}$ & $\mathrm{M}$ & B & $\mathrm{M}$ & $\mathrm{M}$ \\
\hline & & kedepan & $\mathrm{S}$ & B & B & $\mathrm{S}$ & B & B \\
\hline & & & B & & & B & & \\
\hline & & menunjukk & B & B & B & B & $\mathrm{M}$ & B \\
\hline & & an hasil & S & S & $\mathrm{S}$ & $\mathrm{S}$ & B & $\mathrm{S}$ \\
\hline & & kary & $\mathrm{H}$ & B & B & B & & B \\
\hline \multirow[t]{5}{*}{3} & \multirow{5}{*}{$\begin{array}{c}\text { Beran } \\
\text { i } \\
\text { menc } \\
\text { oba }\end{array}$} & menerima & $\overline{\mathrm{M}}$ & B & $\mathrm{M}$ & B & M & $\mathrm{M}$ \\
\hline & & kegiatan & B & $\mathrm{S}$ & B & $\mathrm{S}$ & B & B \\
\hline & & yang $\mathrm{s}$ & & B & & $\mathrm{B}$ & & \\
\hline & & berani & M & B & $\mathrm{M}$ & B & $\mathrm{M}$ & $\mathrm{M}$ \\
\hline & & & B & $\begin{array}{l}S \\
B\end{array}$ & B & $\begin{array}{l}S \\
B\end{array}$ & B & B \\
\hline \multirow[t]{7}{*}{4} & \multirow{7}{*}{$\begin{array}{c}\text { Kema } \\
\text { uan } \\
\text { berta } \\
\text { nya } \\
\text { dalam } \\
\text { memi } \\
\text { nta } \\
\text { bantu }\end{array}$} & & B & $\mathrm{B}$ & $\mathrm{M}$ & $\mathrm{M}$ & $\mathrm{M}$ & $\mathrm{M}$ \\
\hline & & meminta & B & B & B & B & B & B \\
\hline & & bantuan & & & & & & \\
\hline & & $\begin{array}{l}\text { teman } \\
\text { kesul }\end{array}$ & & & & & & \\
\hline & & men & B & B & B & B & M & B \\
\hline & & bantuan & $\mathrm{S}$ & S & $\mathrm{S}$ & $\mathrm{S}$ & B & $\mathrm{S}$ \\
\hline & & guru & $\mathrm{H}$ & B & $\mathrm{B}$ & B & & $\mathrm{H}$ \\
\hline
\end{tabular}

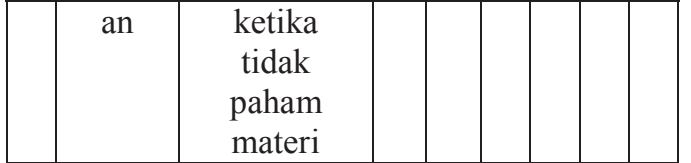

Jika dilihat pada tabel 5 dapat dinyatakan bahwa hasil observasi menunjukkan aspek Berani Ambil Risiko nilai tertinggi pada item kemampuan bertanya dalam meminta bantuan dan rasa percaya diri. Terbukti bahwa dari keenam subjek mencapai penilaian rata-rata $\mathrm{BSH}$ (berkembang sesuai harapan) dan BSB (berkembang sangat bagus). Jadi, anak mampu menunjukkan sikap berani mengambil risiko saat ada kemampuan bertanya dalam meminta bantuan yang dimaksud adalah anak meminta bantuan guru ketika tidak paham materi kegiatan berwirausaha dan memiliki rasa percaya diri dibuktikan dengan mampu menunjukkan hasil karya. Selain itu yang menjadi catatan anak sadar bahwa dalam pembelajaran kewirausahaan ini ada kompetisi, sehingga secara mandiri anak mencoba untuk tidak meminta bantuan pada teman saat dirinya mengalami kesulitan.

Tabel 6. Hasil Rangkuman Observasi Kreativitas Entrepreneurial Leadership Subjek

\begin{tabular}{|c|c|c|c|c|}
\hline $\begin{array}{l}\mathbf{N} \\
\mathbf{0}\end{array}$ & $\begin{array}{l}\text { Indik } \\
\text { ator }\end{array}$ & Item & Pernyataan & $\begin{array}{l}\text { Nil } \\
\text { ai }\end{array}$ \\
\hline \multirow[t]{10}{*}{1} & \multirow[t]{10}{*}{$\begin{array}{c}\text { Kreat } \\
\text { if }\end{array}$} & \multirow[t]{4}{*}{$\begin{array}{c}\text { Berpikir } \\
\text { lancar }\end{array}$} & $\begin{array}{c}\text { menghasilkan } \\
\text { gagasan } \\
\text { dengan cepat }\end{array}$ & 90 \\
\hline & & & $\begin{array}{c}\text { mengembangk } \\
\text { an gagaan }\end{array}$ & 91 \\
\hline & & & $\begin{array}{l}\text { menjawab } \\
\text { pertayaan }\end{array}$ & 81 \\
\hline & & & $\begin{array}{c}\text { tanggap } \\
\text { memperbaiki } \\
\text { kesalahan }\end{array}$ & 58 \\
\hline & & \multirow[t]{2}{*}{$\begin{array}{c}\text { Berpikir } \\
\text { luwes }\end{array}$} & $\begin{array}{c}\text { menghasilkan } \\
\text { gagasan } \\
\text { bervariasi }\end{array}$ & 92 \\
\hline & & & $\begin{array}{c}\text { memecahkan } \\
\text { masalah }\end{array}$ & 72 \\
\hline & & \multirow[t]{3}{*}{$\begin{array}{l}\text { Berpikir } \\
\text { orisional }\end{array}$} & $\begin{array}{l}\text { mengajukan } \\
\text { gagasan baru }\end{array}$ & 85 \\
\hline & & & $\begin{array}{c}\text { membuat } \\
\text { kombinasi } \\
\text { kegiatan }\end{array}$ & 82 \\
\hline & & & $\begin{array}{l}\text { menghasilkan } \\
\text { karyaberbeda }\end{array}$ & 91 \\
\hline & & Memerin & menjelaskan & 83 \\
\hline
\end{tabular}




\begin{tabular}{|c|c|c|c|c|}
\hline & & \multirow[t]{2}{*}{ ci } & $\begin{array}{c}\text { gagasan } \\
\text { dengan rinci }\end{array}$ & \\
\hline & & & $\begin{array}{c}\text { menghasilkan } \\
\text { karya dengan } \\
\text { teliti }\end{array}$ & 68 \\
\hline & & \multirow[t]{2}{*}{ Menilai } & $\begin{array}{c}\text { mengutarakan } \\
\text { pendapat }\end{array}$ & 81 \\
\hline & & & $\begin{array}{l}\text { menentukan } \\
\text { pilihan secara } \\
\text { mandiri }\end{array}$ & 81 \\
\hline \multirow[t]{6}{*}{2} & \multirow[t]{6}{*}{$\begin{array}{c}\text { Inova } \\
\text { si }\end{array}$} & \multirow[t]{2}{*}{$\begin{array}{l}\text { Terbuka } \\
\text { pada } \\
\text { perubaha } \\
n\end{array}$} & $\begin{array}{l}\text { menghasilkan } \\
\text { karya baru } \\
\text { dari pendapat } \\
\text { orlan }\end{array}$ & 62 \\
\hline & & & $\begin{array}{c}\text { mencipkan hal } \\
\text { baru sesuai } \\
\text { keinginan }\end{array}$ & 80 \\
\hline & & \multirow[t]{2}{*}{$\begin{array}{l}\text { Pandang } \\
\text { an } \\
\text { peluang }\end{array}$} & $\begin{array}{c}\text { mengkreasika } \\
\text { n bahan baru } \\
\text { sesuai ide }\end{array}$ & 76 \\
\hline & & & $\begin{array}{l}\text { melihat situasi } \\
\text { untuk } \\
\text { berkompetisi }\end{array}$ & 79 \\
\hline & & \multirow[t]{2}{*}{$\begin{array}{l}\text { Perencan } \\
\text { aan }\end{array}$} & $\begin{array}{c}\text { mengambarka } \\
\mathrm{n} \text { awal rencana } \\
\text { impian }\end{array}$ & 83 \\
\hline & & & $\begin{array}{l}\text { menceritakan } \\
\text { sederhana } \\
\text { tentang } \\
\text { rencana usaha }\end{array}$ & 82 \\
\hline \multirow[t]{5}{*}{3} & \multirow[t]{5}{*}{$\begin{array}{c}\text { Intuis } \\
\mathrm{i}\end{array}$} & & $\begin{array}{c}\text { merasakan } \\
\text { menjadi } \\
\text { pengusaha }\end{array}$ & 74 \\
\hline & & & $\begin{array}{c}\text { menjelaskan } \\
\text { spontan } \\
\text { gambar } \\
\text { usahanya }\end{array}$ & 80 \\
\hline & & & $\begin{array}{c}\text { menghasilkan } \\
\text { hasil karya } \\
\text { sesuai hatinya }\end{array}$ & 77 \\
\hline & & & $\begin{array}{c}\text { menggambil } \\
\text { hikmah akan } \\
\text { yang sudah } \\
\text { dilakukan }\end{array}$ & 69 \\
\hline & & & $\begin{array}{c}\text { memberi } \\
\text { kesan tentang } \\
\text { yang sudah } \\
\text { dipelajari }\end{array}$ & 75 \\
\hline \multirow[t]{4}{*}{4} & \multirow[t]{4}{*}{$\begin{array}{l}\text { Motiv } \\
\text { asi }\end{array}$} & \multirow{3}{*}{$\begin{array}{l}\text { Kesenan } \\
\text { gan, } \\
\text { kenikam } \\
\text { atan } \\
\text { belajar }\end{array}$} & $\begin{array}{c}\text { kemauan } \\
\text { mengikuti } \\
\text { kegiatan }\end{array}$ & 98 \\
\hline & & & $\begin{array}{c}\text { senang } \\
\text { mengikuti } \\
\text { kegiatan }\end{array}$ & $\begin{array}{c}10 \\
7\end{array}$ \\
\hline & & & $\begin{array}{c}\text { fokus } \\
\text { mengikuti } \\
\text { kegiatan }\end{array}$ & 88 \\
\hline & & $\begin{array}{l}\text { Penguasa } \\
\text { an materi }\end{array}$ & $\begin{array}{c}\text { melakukan } \\
\text { kegiatan yang }\end{array}$ & 82 \\
\hline
\end{tabular}

\begin{tabular}{|c|c|c|c|c|}
\hline & & & $\begin{array}{c}\text { sudah } \\
\text { dipelajari }\end{array}$ & \\
\hline & & & $\begin{array}{c}\text { mengungkapk } \\
\text { an kegiatan } \\
\text { yang dipelajari }\end{array}$ & 77 \\
\hline & & $\begin{array}{c}\text { Doronga } \\
\mathrm{n} \text { ingin } \\
\text { tahu kuat }\end{array}$ & $\begin{array}{c}\text { aktif bertanya, } \\
\text { berpartisipasi } \\
\text { dalam } \\
\text { pembelajaran }\end{array}$ & 63 \\
\hline & & & $\begin{array}{l}\text { rasa ingin tahu } \\
\text { tinggi }\end{array}$ & 79 \\
\hline & & $\begin{array}{l}\text { Keuletan } \\
\text { mengerja } \\
\text { kan tugas }\end{array}$ & $\begin{array}{c}\text { menyelesaikan } \\
\text { kegiatan } \\
\text { hingga akhir }\end{array}$ & $\begin{array}{c}10 \\
2\end{array}$ \\
\hline & & & $\begin{array}{c}\text { menerima } \\
\text { tugas yang } \\
\text { diberikan guru }\end{array}$ & 98 \\
\hline & & $\begin{array}{c}\text { Keterliba } \\
\tan \end{array}$ & $\begin{array}{c}\text { mengikuti } \\
\text { proses cara } \\
\text { pembuatan } \\
\text { karya }\end{array}$ & $\begin{array}{c}10 \\
6\end{array}$ \\
\hline & & & $\begin{array}{c}\text { terlibat } \\
\text { membuat } \\
\text { karya } \\
\end{array}$ & $\begin{array}{c}10 \\
5\end{array}$ \\
\hline 5 & $\begin{array}{c}\text { Beran } \\
\text { i }\end{array}$ & $\begin{array}{c}\text { Berani } \\
\text { tanya dan }\end{array}$ & $\begin{array}{c}\text { mampu } \\
\text { bertanya }\end{array}$ & 72 \\
\hline & $\underset{1}{\mathrm{Ambi}}$ & ditanya & $\begin{array}{c}\text { berani } \\
\text { menjawab }\end{array}$ & 81 \\
\hline & $\begin{array}{l}\text { Risik } \\
\text { o }\end{array}$ & $\begin{array}{c}\text { Rasa } \\
\text { percaya }\end{array}$ & $\begin{array}{c}\text { tampil } \\
\text { kedepan }\end{array}$ & 71 \\
\hline & & diri & $\begin{array}{c}\text { menunjukkan } \\
\text { hasil karya }\end{array}$ & 89 \\
\hline & & $\begin{array}{c}\text { Berani } \\
\text { mencoba }\end{array}$ & $\begin{array}{c}\text { menerima } \\
\text { kegiatan yang } \\
\text { sulit } \\
\end{array}$ & 70 \\
\hline & & & $\begin{array}{c}\text { berani } \\
\text { mencoba hal } \\
\text { baru }\end{array}$ & 75 \\
\hline & & $\begin{array}{c}\text { Kemauan } \\
\text { bertanya } \\
\text { dalam } \\
\text { meminta }\end{array}$ & $\begin{array}{c}\text { berani } \\
\text { meminta } \\
\text { bantuan teman } \\
\text { saat kesulitan }\end{array}$ & 52 \\
\hline & & bantuan & $\begin{array}{c}\text { meminta } \\
\text { bantuan guru } \\
\text { ketika tidak } \\
\text { paham materi }\end{array}$ & 95 \\
\hline
\end{tabular}

Berdasarkan tabel di atas dapat dilihat bahwa terdapat lima aspek yang diamati yakni kreativitas, inovasi, intuisi, motivasi, dan berani mengambil risiko. Kelima aspek di atas diperoleh hasil bahwa aspek pertama kreatif, anak meningkat secara kreatif saat : 1) anak mampu berpikir luwes, yakni anak mampu menghasilkan gagasan/ide yang bervariasi; 2) anak mampu berpikir lancar, yakni anak 
mampu mengembangkan gagasan/ide yang sudah dimilikinya: 3) anak mampu berpikir orisinil, yakni anak mampu menghasilkan karya yang berbeda. Aspek kedua inovasi, anak mampu berinovasi saat; 1) anak memiliki perencanaan, yakni mampu menggambarkan awal rencana impian dan menceritakan rencana sederhana terkait usahanya; 2) anak dapat terbuka terhadap perubahan, yakni anak mampu menciptakan hal-hal baru sesuai keinginan sendiri. Aspek ketiga intuisi, yakni saat: 1) anak mampu menjelaskan gambaran usahanya secara spontan; 2) anak mampu menghasilkan karya sesuai kata hati; dan 3) anak mampu memberikan kesan tentang apa yang sudah dipelajari. Aspek keempat motivasi nampak saat; 1) anak senang, menikmati selama proses belajar yakni anak senang mengikuti kegiatan dan; 2) memiliki keterlibatan yang tinggi pada tugas yakni anak mengikuti proses sekaligus cara pembuatan karya dan terlibat langsung membuat karya. Aspek kelima keberanian mengambil risiko nampak saat: 1) memiliki kemauan untuk bertanya dalam meminta bantuan, yakni anak meminta bantuan pada guru ketika tidak paham materi; 2) memiliki rasa percaya diri yakni anak mampu menunjukkan hasil karya dan; 3) berani ditanya yakni anak berani menjawab. Jika disimpulkan nilai aspek tertinggi terdapat pada aspek motivasi dan kreativitas.

\section{Pembahasan}

Dalam proses pelaksanaan selalu membutuhkan stimulasi. Menurut Hurlock, 2007 dalam memberikan stimulasi harus tepat sesuai tahapan usianya. Stimulasinya berupa informasi tentang bagaimana menjadi seorang pengusaha. Ada dua karakter seorang entrepreneur yakni Pertama sebagai creator dalam menciptakan usaha atau bisnis yang benarbenar baru yang dalam hal ini mengarah ke pengembangan kreativitas. Kedua, sebagai innovator, menggagas pembaruan baik dalam produksi, pemasaran, maupun pengelola dari usaha yang sudah ada sehingga menjadi lebih baik mengarah pada jiwa kepemimpinan. Dalam pembentukan karakter tersebut nampak bahwa sudah mampu mengembangkan gagasan sekaligus menghasilkan gagasan yang bervariasi hingga sampai pada hasil karya yang berbeda. Sehingga anak sudah dapat dikatakan memiliki kreativitas dalam berwirausaha dimana mampu berpikir lancar, luwes, dan orisinil. Hal ini senada dengan pengungkapan dari Williams dalam Munandar (2009) yang menyatakan bahwa kreativitas berhubungan dengan aspek Kognitif, yakni kemampuan berpikir kreatif meliputi keterampilan berpikir lancar, keterampilan berpikir luwes, dan keterampilan berpikir orisinil.

Kreativitas entrepreneurial leadership nampak pada beberapa aspek yang diamati mulai dari kreativitas, inovasi, intuisi, dan motivasi, serta keberanian mengambil risiko. Dari kelima aspek di atas yang memiliki nilai tertinggi adalah aspek motivasi dan kreatif. a) motivasi, yakni memiliki keterlibatan yang tinggi terhadap tugas dan senang sekaligus menikmati ditiap kegiatan belajar. Motivasi selalu muncul ditiap kegiatan, anak selalu diberi stimulus berupa motivasi kata-kata "aku pasti bisa" membuat anak senang dan antusias melakukan kegiatan sampai akhir. Sedangkan b) kreatif, yakni mampu berpikir lancar dan berpikir luwes. Pada aspek kreativitas sebenarnya sudah terlihat saat anak-anak terpilih sebagai subjek penelitian anak diminta untuk menunjukkan kreativitasnya lewat sebuah gambar, dan nampak bahwa anak mampu mengembangkan dan menghasilkan sebuah gagasan.

Adapun faktor-faktor pendukung dalam proses pengembangan kreativitas entrepreneurial leadership anak usia dini saat pembelajaran antara lain, yakni:

1. Sarana belajar

Dalam hal ini sarana belajar dianggap sangat penting. Selama proses kegiatan anak merasa terbantu saat sarana belajar 
ada dan tercukupi dalam pengembangan kreativitas, misal media untuk anak usia dini adalah Alat Pembelajaran Edukatif (APE). Senada dengan pengertian dari sarana belajar itu sendiri adalah semua keperluan yang diperlukan dalam proses belajar agar pencapaian tujuan dapat berjalan dengan lancar, teratur, efektif dan langsung ( Roestiyah, 2008) khususnya dalam hal merangsang dorongan untuk eksperimen dan eksplorasi sesuai karakteristik anak usia dini yakni memiliki rasa ingin tahu yang tinggi (Hartati, 2005);

2. Kemenarikan guru

Dalam hal ini, kemenarikan guru bukan hanya saat proses pembelajaran baik dalam menyiapkan media pembelajaran yang kreatif sampai dengan cara mengajar yang menstimulasi anak untuk kreatif tetapi juga seringnya memberikan motivasi kepada anakanak saat proses pembelajaran khususnya dalam pengembangan kreativitas. Senada dengan yang diungkapkan oleh Dajamarah (2010) bahwa peran dari seorang guru memiliki faktor yang begitu penting dalam meningkatkan kemauan belajar anak. Guru harus dapat memotivasi dan memberikan arahan kepada anak bagaimana cara belajar yang baik dan mengembangkan potensi;

3. Peran orang tua

Orang terdekat anak adalah orangtua, disini dilihat dari sejauh apa keterlibatan orangtua ikut serta dalam mendukung tiap proses kegiatan sehingga membuat anak semangat. Peran orangtua disini meliputi motivator, fasilitator, dan mediator. Dalam hal a) motivator, orang tua harus senantiasa memberikan dorongan terhadap anak dengan cara memberikan kenyakinan bahwa anak mampu mengembangkan gagasan/ide kreatif nya; b) fasilitator, kunjungan orangtua ke sekolah untuk mengetahui perkembangan anak di sekolah sekaligus ikut berperan aktif melalui kegiatan sekolah seperti kerjasama anak dan orangtua; c) mediator, orangtua harus memiliki pengetahuan dan pemahaman dalam mendidik anak khususnya sebagai perantara dan penengah. Dalam hal ini orang tua diminta untuk dapat menjadi jembatan terhadap anak tentang apa yang ingin dilakukan anak, sehingga pembelajaran dirumah dan disekolah bisa seimbang. Hal di atas senada dengan apa yang ada dalam Depdikbud, 2005 yang menyatakan bahwa peran orangtua dalam mendukung kegiatan TK, yaitu menyediakan media/bahan praktik merupakan salah satu faktor pendukung.

\section{SIMPULAN}

Berdasarkan hasil penelitian di atas maka dapat disimpulkan bahwa anak dikatakan kreativitas entrepreneurial leadership di pembelajaran kewirausahaan saat memiliki karakteristik antara lain: a) motivasi, yakni memiliki keterlibatan yang tinggi terhadap tugas dan senang sekaligus menikmati ditiap kegiatan pembelajaran dan; b) kreatif, yakni mampu berpikir lancar dan berpikir luwes. Sedangkan Faktor pendukung dalam pengembangan kreativitas entrepreneurial leadership anak usia dini adalah sarana belajar, kemenarikan guru, dan peran orangtua.

\section{DAFTAR PUSTAKA}

Dajamarah, S., B. 2010. Strategi Belajar Mengajar. Jakarta: Rieneka Cipta

Hartati, S. 2005. Perkembangan Belajar Pada Anak Usia Dini. Depdiknas.

Hidayah, C. 2014. Pengembangan Kreativitas Anak Usia Dini Berbasis Pendidikan Tauhid Dan Entrepreneurship (Penelitian di TK Khalifah Gedong Kuning Yogyakarta). Tesis. Yogyakarta: Program Pascasarjana UIN Sunan Kalijaga

Hurlock, E., B. 2007. Perkembangan Anak Jilid I. Yogyakarta: Erlangga. 
Moleong, L., J. 2012. Metodologi Penelitian Kualitatif Edisi Refisi. Bandung: Remaja Rosdakarya.

Munandar, U. 2009. Pengembangan Kreativitas Anak Berbakat. Jakarta: Rineka Cipta.

Nurhayati. 2011. Peningkatan Kreativitas Anak Usia Dini Dengan Bereksplorasi Melalui Koran Bekas Di Taman Kanak-Kanak Aisyiyah 2 Duri. Jurnal Pesona PAUD. Vol 1 (1), Hal 1-10.

Roestiyah. 2008. Strategi Belajar Mengajar dalam CBSA. Jakarta: Rineka Cipta

Sugianto., E., Y \& Sutanto., E., M. 2013. Pengaruh Entrepreneurial Leadership Terhadap Iklim Organisasional, Kreativitas, Dan Inovasi Karyawan Bagian Produksi Pada Sbo TV. Jurnal AGORA, Vol 1 (2) Hal 1-9. 